\title{
PENINGKATAN KEMAMPUANGUIDING PADA POKDARWIS ALAM PUNCAK LANDEP MELALUI PELATIHAN BERLANDASKAN FALSAFAH TRI HITA KARANA
}

\author{
Ketut Chandra Adinata Kusuma ${ }^{1}$, Ni Putu Dwi Sucita Dartini ${ }^{2}$, Luh Putu Tuti Ariani ${ }^{3}$, \\ Syarif Hidayat ${ }^{4}$ \\ 1.3.4 Prodi Pendidikan Kepelatihan Olahraga, Universitas Pendidikan Ganesha \\ ${ }^{2}$ Prodi Pendidikan Jasmani, Kesehatan dan Rekreasi, Universitas Pendidikan Ganesha \\ e-mail: chandra.adinata@undiksha.ac.id, sucita.dartini@undiksha.ac.id, \\ ariani_tuti@yahoo.co.id,syarif.hidayat@undiksha.ac.id
}

\begin{abstract}
Abstrak
Semakintumbuhnyajumlah wisatawandenganminatkhusus, yakni sport tourismkhususnya aktivitas trekking yang dipadukan dengan atraksi budaya/kearifan lokal mendorong upaya peningkatan kualitas pramuwisata. Pokdarwis alam puncak landep dibentuk untuk menjual usaha jasa pada bidang pemanduan belum memiliki pengetahuan dan pemahaman tentang: (1) potensi atraksi budaya yang dapat dipadukan dengan aktivitas trekking, (2) prosedur pemanduan yang berlandaskan falsafah Tri Hita Karana, (3) keterampilan berbahasa inggris. Untuk itu, telah dilakukan pelatihan pemanduan trekking berlandaskan falsafah Tri Hita Karana. Tujuan pelatihan ini untuk meningkatkan kemampuan guiding berlandaskan falsafah Tri Hita Karana. Metode yang digunakan adalah diskusi dan praktik. Hasil pelatihan menunjukan ada peningkatan pengetahuan dan pemahaman memadukan antara atraksi budaya dengan aktivitas trekking dan praktik prosedur pemanduan yang dipadukan dengan cara menggunakan bahasa inggris. Dengan demikian, Pokdarwis dapat meningkatkan kemampuan guiding melalui pelatihan berlandaskan falsafah Tri Hita Karana.
\end{abstract}

Kata kunci: Pemanduan trekking, pelatihan,Tri Hita Karana

\begin{abstract}
The growing number of tourists with special interests, namely sport tourism, especially trekking activities combined with cultural attractions/local wisdom encourages efforts to improve the quality of tour guides. Pokdarwis Alam Puncak Landep was formed to sell service businesses in the field of guidance that do not have the knowledge and understanding of: (1) potential cultural attractions that can be combined with trekking activities, (2) guiding procedures based on the local wisdom, (3) English language skills. To that end, trekking guiding training has been conducted based on the Tri Hita Karanaphilosophy. The purpose of this training is to improve guiding skills based on the Tri Hita Karanaphilosophy. The method used is discussion and practice. The results of the training show that there is an increase in knowledge and understanding of combining cultural attractions with trekking activities and practicing guiding procedures combined with using English. Thus, Pokdarwis can improve their guiding ability through training based on the Tri Hita Karanaphilosophy.
\end{abstract}

Keywords: Trekking guidance, training, Tri Hita Karana

\section{PENDAHULUAN}

Indonesia hingga kini menjadikan sektor pariwisata sebagai salah satu penyumbang devisa utama. Bahkan Menteri Pariwisata Republik Indonesia optimistis mulai tahun 2019 dan lima tahun ke depan, industri pariwisata menjadi salah satu yang menyumbangkan devisa terbesar, mengalahkan sektor lain dengan proyeksi nilai sebesar US\$20 miliar 
(Rosana, 2019).Industri pariwisata telah mulai mengakui keberadaan sport tourism, yaitu pengalaman perjalanan yang keterlibatan atau melihat kegiatan yang berhubungan dengan olahraga. Olahraga adalah segala kegiatan yang sistematis untuk mendorong, membina, serta mengembangkan potensi jasmani, rohani, dan sosial (Pasal 1 ayat 4 UU RI No. 3 Tahun 2005).Perkembangan yang cukupmenarikadalahsemakintumbuhnyajum lah wisatawandenganminatkhusus. Menurut Suyitno (2013) yang dimaksud dengan daya tarik wisata minat khusus adalah daya tarik wisata yang dikembangkan dengan lebih banyak berbasis pada aktivitas untuk pemenuhan keinginan wisatawan secara spesifik.

Jadi perpaduan pengembangan olahhraga dan pariwisata di atas sangat gayut dengan Undang Undang Nomor 10 Tahun 2009 Pasal 3 yang menyatakan bahwa kepariwisataan berfungsi memenuhi kebutuhan jasmani, rohani, dan intelektual setiap wisatawan dengan rekreasi dan perjalanan serta meningkatkan pendapatan negara untuk mewujudkan kesejahteraan rakyat. Sehingga untuk mendukung kepariwisataan maka dibutuhkan Sumber Daya Alam (SDA) dan Sumber Daya Manusia (SDM). SDM dibidang pariwisata identik dengan sebutan pramuwisata. Pramuwisata olahraga adalah orang yang sangat berperan penting dalam pelaksanaan kegiatan olahraga di tempat wisata. Pramuwisata olahraga yang ahli dan profesional harus segera disiapkan oleh semua pihak yang berkecimpung dalam industri olahraga pariwisata maupun oleh pemerintah. Selama ini pramuwisata yang khusus menangani bidang olahraga pariwisata belum disiapkan dengan profesional (Hidayat, 2014).

Berkaitan dengan pengembangan olahraga pariwisata di Kabupaten Buleleng, khususnya di Kecamatan Sukasada maka bidang yang memungkinkan dan cocok untuk dikembangkan adalah olahraga trekking(Hidayat, 2007). Desa Panji Anom yang merupakan bagian dari Kecamatan Sukasada,memiliki topografi seperti hutan lindung, air terjun, persawahan dan perkebunan yang merupakan keunggulan tersendiri sebagai penunjang aktivitas
trekking.Pembangunan dan pengembangan serta penyelenggaraan olahraga pariwisata, khususnya aktivitas trekking harus sesuai dengan Perda Provinsi Bali Nomor 2 tahun 2012 tentang Kepariwisataan Budaya Bali Pasal 2 Bab II yang menyatakan bahwa "Penyelenggaraan Kepariwisataan Budaya Bali dilaksanakan berdasarkan pada asas manfaat, kekeluargaan, kemandirian, keseimbangan, kelestarian, partisipatif, berkelanjutan, adil dan merata, demokratis, kesetaraan dan kesatuan yang dijiwai oleh nilai-nilai Agama Hindu dengan menerapkan falsafah Tri Hita Karana".
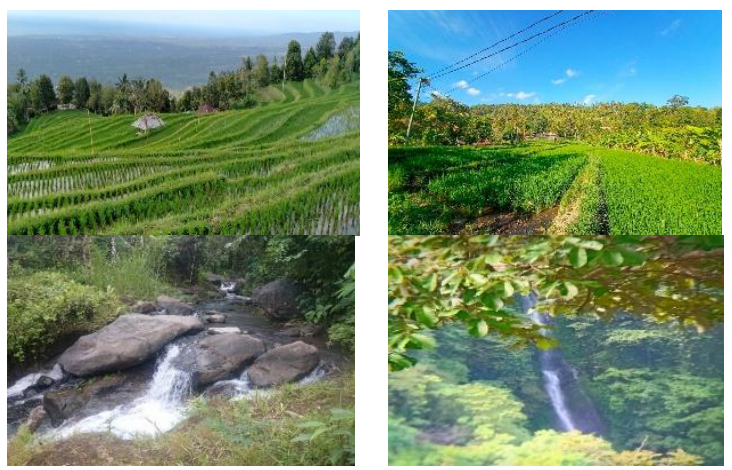

Gambar 1. Potensi alam Desa Panji Anom

Pokdarwis Alam Puncak Landep Desa Panji Anom mempunyai usaha utama yaitu memandu wisatawan untuk melakukan aktivitas trekking serta memperkenalkan atraksi budaya atau kearifan lokal. Namun, persoalan yang ada di Pokdarwis Alam Puncak Landep adalah belum memiliki pemahaman tentang tata caraguiding aktivitas trekking dengan mengkombinasikan atraksi budaya atau kearifan lokal. Sehingga memberikan pelatihan guiding aktivitas trekking berlandaskan falsafah Tri Hita Karanasangat dibutuhkan oleh Pokdarwis alam puncak landep.Tri Hita Karanaadalah kehidupan yang seimbang antara berbakti kepada Tuhan (prajapati) mengabdi kepada semua umat manusia (praja) dan menyayangi alam lingkungan (kamadhuk) berdasarkan yadnya yang merupakan sumber tattwa kebudayaan Bali (Purana, 2016: 74). Jika kemampuan memandu yang profesional dipadukan dengan mengaplikasikan nilai-nilai Tri Hita Karanamaka niscaya akan mendatangkan keuntungan bagi semua pihak, baik pihak 
pemandu maupun wisatawan itu sendiri.Sehingga tujuan dari kegiatan ini adalah untuk meningkatkan kemampuan guiding berlandaskan falsafah Tri Hita Karana pada Pokdarwis Alam Puncak Landep.

\section{METODE}

Metode yang digunakan untuk memecahkan masalah di atas adalah diskusi dan praktik. Kombinasi kedua metode tersebut lebih efektif daripada menggunakan metode ceramah dan diakhiri tes tertulis. Keterkaitan masalah, metode, dan bentuk kegiatan disajikan pada tabel 1 . Keberhasilan program pelatihan dirancang melalui rancangan evaluasi. Rancangan evaluasi program ini mengaitkan tujuan, indikator keberhasilan, dan cara pengukuran seperti tersaji pada tabel 2 .

Tabel 01. Keterkaitan Masalah, Metode, dan Bentuk Kegiatan

\begin{tabular}{|c|c|c|c|}
\hline No & Masalah & Metode & Bentuk Kegiatan \\
\hline 1 & $\begin{array}{l}\text { Pokdarwis kurang mampu } \\
\text { mengemas aktivitas trekking } \\
\text { dengan atraksi budaya atau } \\
\text { kearifan lokal. }\end{array}$ & Diskusi & $\begin{array}{l}\text { Identifikasi bentuk-bentuk atraksi } \\
\text { budaya yang ada di Desa Panji Anom } \\
\text { seperti proses pembuatan air } \\
\text { nira/tuak, permainan tradisional, } \\
\text { proses bertani dan berkebun. }\end{array}$ \\
\hline 2 & $\begin{array}{l}\text { Pokdarwis kurang memahami } \\
\text { prosedur memandu/guiding } \\
\text { aktivitas trekking yang } \\
\text { berkearifan lokal. }\end{array}$ & $\begin{array}{l}\text { Diskusi dan } \\
\text { praktik }\end{array}$ & 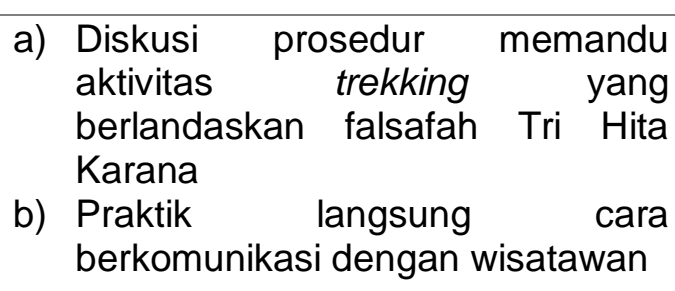 \\
\hline 3 & $\begin{array}{l}\text { Pokdarwis belum mampu } \\
\text { berkomunikasi menggunakan } \\
\text { bahasa inggris. }\end{array}$ & Praktik & $\begin{array}{l}\text { Tiap peserta berbicara menggunakan } \\
\text { bahasa inggris saat memperkenalkan } \\
\text { diri, menunjukan arah jalan/rute, } \\
\text { menyampaikan estimasi waktu } \\
\text { beraktivitas. }\end{array}$ \\
\hline
\end{tabular}

Tabel 02. Rancangan Evaluasi

\begin{tabular}{|c|c|c|c|}
\hline No & Tujuan & Indikator keberhasilan & Cara pengukuran \\
\hline 1 & \begin{tabular}{lr}
\multicolumn{2}{l}{ Pokdarwismendapatkan } \\
pengetahuan & tentang \\
identifikasi & atraksi \\
budaya/kearifan lokal yang \\
dapat dikemas di dalam \\
aktivitas trekking.
\end{tabular} & $\begin{array}{l}\text { Peserta dapat } \\
\text { menyebutkan bentuk- } \\
\text { bentuk aktivitas dari } \\
\text { atraksi budaya/kearifan } \\
\text { lokal. }\end{array}$ & $\begin{array}{l}\text { Diskusi/Tanya jawab } \\
\text { secara lisan. }\end{array}$ \\
\hline 2 & $\begin{array}{l}\text { Pokdarwis mendapatkan } \\
\text { pengetahuan dan keterampilan } \\
\text { tentang prosedur } \\
\text { memandu/guiding aktivitas } \\
\text { trekking yang berkearifan lokal. }\end{array}$ & $\begin{array}{l}\text { Peserta dapat } \\
\text { menyebutkan dan } \\
\text { mempraktikan prosedur } \\
\text { memandu/guiding } \\
\text { aktivitas trekking yang } \\
\text { berlandaskan falsafah } \\
\text { Tri Hita Karana. }\end{array}$ & $\begin{array}{l}\text { Pokdarwis mempraktikan } \\
\text { prosedur } \\
\text { memandu/guiding } \\
\text { aktivitas trekking } \\
\text { berlandaskan falsafah Tri } \\
\text { Hita Karana. }\end{array}$ \\
\hline
\end{tabular}




$\begin{array}{lr}\text { Pokdarwis } & \text { mendapatkan } \\ \text { pengetahuan dan } & \text { keterampilan } \\ \text { berkomunikasi } & \text { sebagai } \\ \text { pemandu } & \text { menggunakan } \\ \text { bahasa inggris } & \end{array}$

Peserta mampu
memperkenalkan diri,
menyampaikan rute
trekking, dan estimasi
waktu trekking dalam
bahasa inggris

Pokdarwis mempraktikan memperkenalkan diri, menyampaikan rute trekking, dan estimasi waktu trekking dalam bahasa inggris.

\section{HASIL DAN PEMBAHASAN HASIL}

Berdasarkan rancangan kegiatan di atas, maka pada bagian berikut ini akan dipaparkan mengenai hasil dari kegiatan pengabdian kepada masyarakat di Desa Panji Anom. Ada tiga tahapan kegiatan yang telah berjalan dengan baik/sesuai dengan rencana. Pada kegiatan tahap pertama, seluruh anggota Pokdarwis dapat mengetahui dan memahami bentuk-bentuk aktivitas/atraksi budaya setempat yang dapat dikombinasikan ke dalam aktivitas trekking. Berdasarkan hasil diskusi antara narasumber dan semua peserta, maka atraksi budaya yang dapat dipadukan di dalam aktivitas trekking antara lain tata cara memanen air nira (tuak) yang manis, bertani dengan cara tradisional di persawahan yang berundak-undak, menikmati suguhan instrument musik tradisional, menyuguhkan permainan megoak-goakan yang juga permainan tradisional asli desa tersebut.

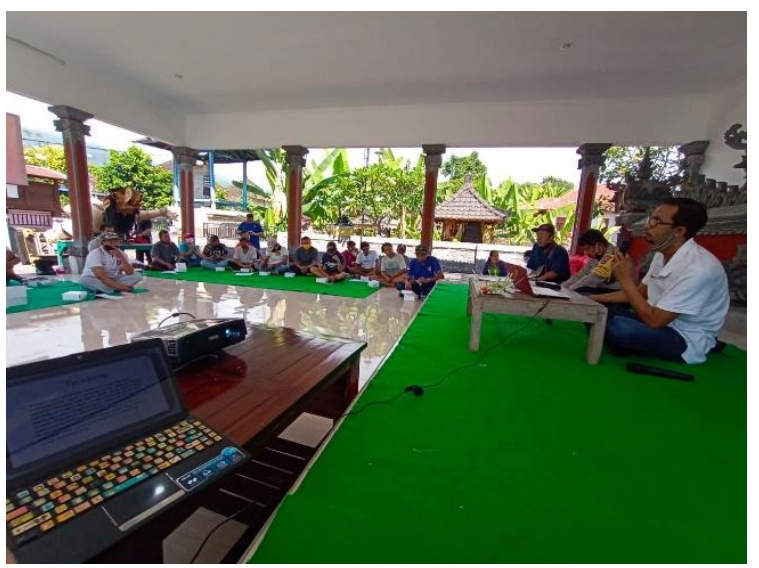

Gambar 2. Diskusi bentuk atraksi budaya yang dapat dipadukan dengan aktivitas trekking

Kegiatan pada tahap kedua yaitu memberikan pemahaman mengenai prosedur memandu/guiding untuk aktivitas trekking kepada Pokdarwis yang berlandaskan pada falsafah Tri Hita
Karana. Proses diskusi di tahapan ini jauh lebih ramai sebab narasumber langsung memberikan kesempatan untuk praktik memulai proses guiding seperti tata cara memberikan salam kepada wisatawan, memperkenalkan diri, memperkenalkan keberadaan desa, menjelaskan rute perjalanan hingga atraksi budaya yang akan dijumpai selama trekking, memberikan peringatan kepada wisatawan terkait jalur aman yang ditempuh.

Tahap terakhir dari kegiatan ini yakni memberikan pelatihan berbahasa inggris kepada seluruh anggota Pokdarwis. Tahap ini masih ada kaitannya dengan kegiatan pada tahap kedua di atas. Semua kegiatan di tahap kedua tersebut disampaikan dalam bahasa inggris. Narasumber juga memberikan kesempatan kepada semua peserta untuk belajar praktik secara langsung. Hasilnya cukup baik, walaupun pengucapannya masih perlu perbaikan/penyempurnaan kembali.

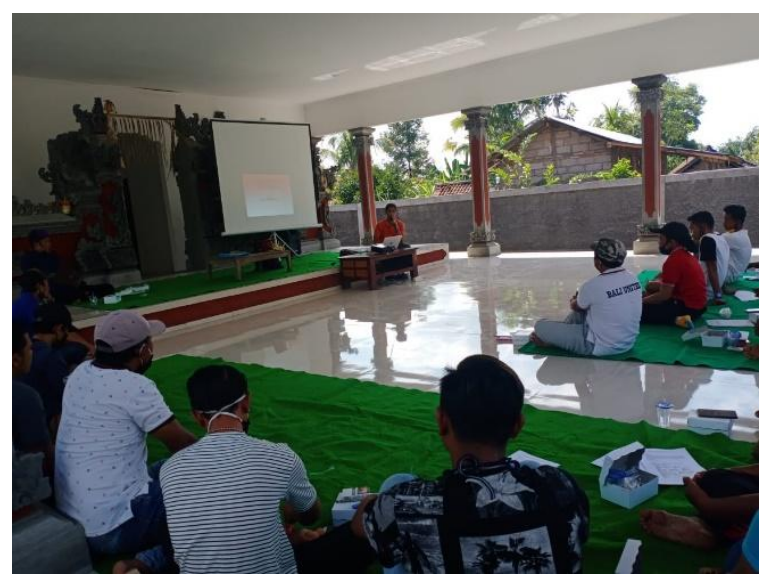

Gambar 3. Diskusi prosedur guiding aktivitas trekking berlandaskan falsafah Tri Hita Karana

\section{PEMBAHASAN}

Secara umum, kegiatan pengabdian kepada masyarakat pada Pokdarwis Alam Puncak Landep Desa Panji Anom yang berlangsung pada hari Minggu 19 Juli 2020 
di Balai Dusun Abasan Desa Panji Anom mulai pukul 09.00 wita sampai pukul 15.00 wita berjalan baik/sesuai rencana. Kegiatan yang dibuka oleh I Ketut Marma Kepala Dusun Lebahsiung, mewakili Kepala Desa Panji Anom dihadiri oleh anggota Pokdarwis yang berjumlah 20 orang dan dihadiri juga oleh Bhabinkamtibmas Desa Panji Anom.

Atraksi budaya lokal yang ada di Desa Panji Anom seperti; proses pembuatan minuman tradisional air nira/tuak yangmanis, proses bertani, pertunjukan permainan tradisional, pertunjukan instrumen musik tradisional akhirnya dapat dikemas ke dalam paket aktivitas trekking. Awalnya, pengetahuan dari Pokdarwis tentang aktivitas trekking hanya sebatas berjalan melintasi alam desa saja. Namun, setelah mendapatkan pelatihan ini maka pengetahuan dan pemahaman Pokdarwis menjadi bertambah.Kegiatan atau aktivitas trekking yang dipadukan dengan kearifan lokal memiliki nilai jual tinggi dan sangat diminati oleh wisatawan (Hidayat, dkk, 2017).

Setelah mengetahui kearifan lokal atau atraksi budaya dapat dipadukan dengan aktivitas trekking, maka langkah selanjutnya meningkatkan kemampuan pemandu dalam melakukan prosedur guiding. Pelatihan guiding berlandaskan falsafah Tri Hita Karana dengan menyisipkan keterampilan berbahasa inggris menjadi solusi untuk meningkatkan kemampuan guiding Pokdarwis Alam Puncak Landep. Pendampingan yang dalam hal ini narasumber berperan sebagai mentor dalam membelajarkan praktik berbahasa inggris sebagai seorang pemandu berdampak pada peningkatan keterampilan walaupun tidak secara signifikan. Sebab keterampilan berbahasa akanberhasil jika dilakukan menjadi sebuah kebiasaan/dilakukan secara kontinyu. Namun aspek lainnya seperti, prosedur yang mesti dilakukan sebagai seorang pemandu aktivitas trekking telah berhasil dikuasai oleh peserta. Berdasarkan hal tersebut maka pelatihan dan pendampingan memiliki pengaruh terhadap peningkatan pengetahuan dan/atau keterampilan Pokdarwis Alam Puncak Landep. Hal yang sama juga disampaikan bahwa pendampingan berpengaruh positif terhadap penambahan pengetahuan dan keterampilan peserta (Muthmainnah, 2012). Menurut Damanik (2013) tingkat pendidikan dan latihan misalnya akan menginformasikan seberapa bermutu suatu jasa pariwisata yang dihasilkan dan dijalankan oleh pelaku pariwisata di destinasi wisata. Sehingga metode seperti ini menjadi sebuah solusi namun jangka waktu pelaksanaanya yang perlu disesuaikan dengan kedalaman permasalahan yang ada.

\section{KESIMPULAN}

Pelatihan guiding berlandaskan falsafah Tri Hita Karana telah meningkatkan pemahaman Pokdarwis dalam memadukan atraksi budaya/kearifan lokal ke dalam aktivitas trekking, mampu memahami dan mempraktikkan prosedur guiding aktivitas trekking baik dalam bahasa Indonesia maupun bahasa inggris.

\section{DAFTAR PUSTAKA}

Damanik, Janianton. 2013. Pariwisata Indonesia (Antara Peluang dan Tantangan). Yogyakarta: Pustaka Pelajar.

Hidayat, Syarif. 2014.Model Pengembangan Pramuwisata Olahraga di Bali. Proseding SENARI II Lemlit Undiksha.

Hidayat, Syarif. 2007.ldentifikasi Pengembangan Olahraga Trekking di Kecamatan Sukasada Buleleng. Jurnal Penelitian dan Pengembangan Sain \& Humaniora. Vol 2 Nomor 2.

Hidayat, Syarif. dkk. 2017. Developing Local Wisdom-Based Trekking to Support Sports Tourism Industry. Proseding The $2^{\text {nd }}$ International Conference on Sports Science, Health, and Physical Education 2017. Bandung: Universitas Pendidikan Indonesia.

Muthmainnah. 2012. Analisis Dampak Pelatihan dan Pendampingan terhadap Pengetahuan, Sikap, dan Praktek Hygiene Sanitasi Makan Ibu Warung Anak Sehat (IWAS). Skripsi (Tidak 
Jurnal Widya Laksana, Vol.10, No.1, Januari 2021

Departemen Gizi Masyarakat, Fakultas Ekologi Manusia, IPB.

Peraturan Daerah Provinsi Bali Nomor 2 Tahun 2012. Kepariwisataan Bali. Denpasar: Sekretaris Daerah Provinsi Bali.

Peraturan daerah Provinsi Bali Nomor 5 tahun 2008. Pramuwisata. Denpasar: Sekretaris Daerah Provinsi Bali.

Purana, I Made. 2016. Pelaksanaan Tri Hita Karana Dalam Kehidupan Umat Hindu. Jurnal Kajian Pendidikan Widya Accarya FKIP Universitas Dwijendra.

Rosana, Francisca Christy. 2019. "5 Tahun Ke Depan Pariwisata Jadi Devisa

Unggulan, Ini Syaratnya". Tempo.

Co. Tersedia pada

https://travel.tempo.co/read/126044

1/5-tahun-ke-depan-pariwisata-jadidevisa-unggulan-ini-syaratnya (Diakses pada tanggal 5 Desember 2019).

Suyitno, Bambang. 2013. Kebijakan Pembangunan Destinasi Pariwisata. Yogyakarta: Gava Media.

UndangUndang Nomor 10 Tahun 2009. Kepariwisataan Indonesia. Jakarta: Biro Humas dan Hukun Kemenpar RI.

Undang Undang Nomor 3 Tahun 2005. Sistem Keolahragaan Nasional. Jakarta: Kemenpora RI. 